\title{
Soil Carbon Sequestration in Novel Ecosystems at Post-Mine Sites-A New Insight into the Determination of Key Factors in the Restoration of Terrestrial Ecosystems
}

\author{
Amisalu Milkias Misebo ${ }^{1,2, *}$, Marcin Pietrzykowski ${ }^{1}$ (D) and Bartłomiej Woś ${ }^{1}$ (D) \\ 1 Department of Ecology and Silviculture, Faculty of Forestry, University of Agriculture in Krakow, \\ Al. 29 Listopada 46, 31-425 Krakow, Poland; m.pietrzykowski@urk.edu.pl (M.P.); wosbart@gmail.com (B.W.) \\ 2 Department of Environmental Science, Wolaita Sodo University, Wolaita Sodo P.O. Box 138, Ethiopia \\ * Correspondence: amisalu.milkias.misebo@student.urk.edu.pl
}

check for

updates

Citation: Misebo, A.M.;

Pietrzykowski, M.; Woś, B. Soil Carbon Sequestration in Novel Ecosystems at Post-Mine Sites-A New Insight into the Determination of Key Factors in the Restoration of Terrestrial Ecosystems. Forests 2022, 13, 63. https://doi.org/10.3390/ f13010063

Academic Editor: Rodney Will

Received: 17 November 2021 Accepted: 30 December 2021

Published: 4 January 2022

Publisher's Note: MDPI stays neutral with regard to jurisdictional claims in published maps and institutional affiliations.

Copyright: (C) 2022 by the authors. Licensee MDPI, Basel, Switzerland. This article is an open access article distributed under the terms and conditions of the Creative Commons Attribution (CC BY) license (https:/ / creativecommons.org/licenses/by/ $4.0 /)$.

\begin{abstract}
Mining activities are one of the main causes of land degradation around the world and reduce the quality of the surrounding ecosystems. Restoration approaches using different vegetations and reclamation methods have been implemented to address this issue. In this review, paper, different studies focusing on the effect of the restoration of mining sites on the accumulation of soil organic carbon (SOC) were analyzed. SOC in reclaimed mining soil (RMS) increased considerably after various restoration efforts were implemented. The amount of SOC accumulated in RMS was mostly influenced by the restoration age, vegetation type, and substrate or type of reclamation used. From the scientific papers analyzed, we found that SOC accumulation increases with restoration age; however, vegetation type and reclamation have varied effects. According to the review, the restoration of mine sites with vegetation resulted in a rate of SOC accumulation ranging from 0.37 to $5.68 \mathrm{Mg}$ SOC ha ${ }^{-1}$ year $^{-1}$. Climate conditions influenced the type of vegetation used for restoration. Regrading, liming, NPK fertilization, and seeding a mix of legumes and grasses were the most efficient reclamation techniques. Additionally, the use of grass and legume better facilitates the early accumulation of SOC compared with afforestation. Thus, the selection of appropriate tree species composition, reclamation treatments, and restoration age are the key factors for a high SOC accumulation rate.
\end{abstract}

Keywords: mining sites; novel ecosystem; soil carbon; reclamation treatments; vegetation type; restoration

\section{Introduction}

In the Anthropocene, human activities, such as mining, have caused large-scale ecosystem disruptions and changes to the earth's surface [1,2]. Human activities have also altered global element cycles, including carbon, while the gradual increase in carbon dioxide content in the atmosphere continues to be a driving factor for climate change.

The removal of vegetation cover and topsoil causes a severe decrease in soil organic carbon (SOC) content, making mining one of the most significant human impacts on the environment [3,4]. Shrestha and Lal [5] found that SOC in reclaimed mine soils decreased by up to $83 \%$ when compared with undisturbed sites. Land productivity is also diminished as a result of soil profile disturbance during mining [6]. The exposed or deposited post-mining substrates become the parent rock of the developing soils called reclaimed mine soils (RMS) or Technosols [7-9]. These substrates typically display a lack of SOM, nutrient deficiency (mainly of nitrogen and phosphorus) and disturbed nutrient ratios, low $\mathrm{pH}$-values, and unfavorable air-water properties $[2,9,10]$.

When it comes to restoring the ecological function of mining sites after exploitation, two basic questions should be considered: succession or reclamation [11]? Succession does not always allow for the restoration of soil function and plant communities in a timely 
manner. As a result, anthropological intervention through reclamation stimulates the longterm process of succession in post-mining sites [10,12]. The reclamation of mining sites improves the productivity of the sites as well as the sequestration of lost carbon $(\mathrm{C})$ and the reduction in $\mathrm{CO}_{2}$ emissions [7]. For example, Pietrzykowski and Socha [13] revealed that Scots pine (Pinus sylvestris L.) productivity in post-mining ecosystems was comparable with that of a managed forest on a natural pine site. As a result, mine heap rehabilitation is critical for the restoration of ecosystem services $[14,15]$. The goal of reclamation (how it will be used later); natural conditions, such as climate, the availability of soil substrates, and water balance; technical (mining) management, including management of rock overburden; and the relief of the site designed for reclamation all influence the design and detailed planning of reclamation treatments $[9,11,13]$. In areas with a well-formed landscape, favorable hydrological conditions, and potentially productive soils, reclamation may entail using biological methods such as agricultural practices, mineral fertilization, and the introduction of appropriate humus-forming vegetation to target and skillfully accelerate soil formation processes. In places with barren or phytotoxic soils (e.g., the acidic and sulfurous Miocene sands, etc.), the basic restoration technique, in addition to appropriate landscape formation and hydrological condition regulation, consists of sealing and neutralization, followed by biological reclamation [16].

Planting vegetation is the most popular biological restoration approach for mining sites $[10,17]$. Mining constrains the establishment of vegetation by affecting essential soil components for plant growth, such as organic matter, microbial activity, and water, as well as by increasing bulk density and heavy metals [17-20]. Reclaiming a rehabilitation site with various methods such as topsoiling (i.e., respreading of salvaged topsoil or spreading of uppermost soil layer from surrounding arable fields), green manure such as lupine and alfalfa, biochar, inclusion of plant litters, fertilizer treatment, and planting of grass and leguminous shrubs aids in the growth of vegetation [21-23]. Planting vegetation at a mining site plays a crucial role in the production of organic matter, which supports soil biota and releases carbon and essential nutrients into the soil [15,24-28]. Improved soil organic matter may also improve the soil moisture-holding capacity and soil cation exchange, which are vital in the restoration of degraded mining soils [29]. Evaluating a mine site after restoration is vital to ensuring successful restoration. Among the reclamation quality indicators, SOC is very reliable, and evaluating its' status over time shows the quality of the reclaimed land $[4,28,30-32]$.

The accumulation rate of SOC in a reclaimed site is affected by different driving factors, such as the age of the stand, the type of vegetation, treatments applied before restoration, the approach of rehabilitation, and agro-climate [13,28,33]. Litterfall from the planted vegetation is one of the major sources of SOC in reclaimed sites, and its accumulation over time has a direct relationship with SOC. The findings of Barliza et al. [34] in spoil heap reclaimed from an opencast coal mine in Colombia indicates that the highest fine litterfall recorded in the 21-year-old site $\left(2.3 \mathrm{Mg} \mathrm{ha}^{-1}\right.$ year $\left.^{-1}\right)$ was more than double that recorded in the 7-year-old site $\left(1.1 \mathrm{Mg} \mathrm{ha}^{-1}\right.$ year $\left.^{-1}\right)$ and concluded the enriching role of litterfall on soil organic matter content and nutrient status with the increasing age of the stand. An increase in the age of the stand also increases the microbial community [35], which results in the decomposition of organic matter and increases the amount of carbon in the soil with increasing age. Mukhopadhyay et al. [36] also concluded that age of reclamation has a significant effect on the nutritional and microbial properties of the mine soils.

Since the beginning of the history of mining, many studies have been conducted on reclamation methods for degraded mining sites to minimize its environmental impact and to enhance ecosystem services in the changing climate. Several studies have evaluated the effects of mining site reclamation on carbon sequestration [33,37-41]. It is critical to review the impact of restored novel ecosystems at post-mine sites on carbon sequestration in light of the increasing amount of greenhouse gases, including $\mathrm{CO}_{2}$, in the Earth's atmosphere. Therefore, the objectives of this review are (i) to compile an overview of the effect of new ecosystems developed at mining sites on SOC accumulation, (ii) to summarize the key 
driving factors affecting the amount of carbon accumulated on reclaimed mining soil, and (iii) to provide a recommendation on reclamation approaches that enhance carbon accumulation for the restoration of mining soil.

\section{Factors Affecting Carbon Accumulation in RMS}

The restoration of mining sites often contributes to SOC accumulation, but its rate may be affected by different factors such as the reclamation method, the age of restoration, the climate, soil properties, soil moisture, and vegetation $[17,28,33,37,42,43]$ (Table 1).

\subsection{The Age of Restoration and Dynamics of SOC Accumulation in Restored Novel Ecosystems}

A chronosequence study of reclaimed mining sites found that carbon stock increases with age $[8,28,47,50,51]$ (Table 1), but this depends on the vegetation type. For example, the increase in SOC with age for deciduous vegetation reaches a maximum at 10 years and then increases at a slower rate, whereas for coniferous vegetation, SOC slowly increases with age up to 40 years [49]. Furthermore, Sperow [56] found that the annual rate of SOC accumulation increases at an increasing rate for the first 11 years for pasture and 13 years for forest and then decreases for the remaining 20 years. The increase in restoration age promotes the growth of various trees, shrubs, and grasses, which contribute to the addition of soil organic matter via litterfall, twigs, and roots and which also serves as a starting point for soil development in post-mining sites [57].

Carbon is added to the soil each year; therefore, the age of restoration increases the SOC. Adeli et al. [58] showed the strong and positive correlation of SOC accumulation with reclamation age for both forest and pasture ecosystems. The higher SOC at the oldest site (17 years old) was due to the accumulation of leaf litter and its decomposition, which forms humus [36]. Additionally, Adeli et al. [58] mentioned the manure addition from grazing wildlife animals as an additional source of SOC under pasture. Ahirwal and Maiti [59] revealed that afforestation with tree species showed a rate of SOC accumulation in the range of 1.2-2.8 Mg SOC ha-1 year-1. As indicated in Table 1, the annual SOC ranged from approximately $0.32 \mathrm{Mg} \mathrm{ha}^{-1}$ [48,49] to $5.0 \mathrm{Mg} \mathrm{ha}^{-1}$ [33,54]; the calculated average annual increment was $1.84 \mathrm{Mg} \mathrm{ha}^{-1}$; and the variation in the annual increment may be due to tree species, climate, and reclamation methods [33,37,42]. Similarly, Pietrzykowski and Krzaklewski [60] also reported SOC accumulation at a rate of $1.5 \mathrm{MgC} \mathrm{ha}^{-1}$ year $^{-1}$ in mine soil in Poland. The findings of Stahl et al. [61] revealed increased SOC content with age and the 22-year-old and 32-year-old reclaimed soils had higher mean SOC contents than the undisturbed soil. This indicates that the age of restoration has a significant impact on the accumulation of SOC in RMS.

\subsection{The Effect of Vegetation Types on SOC Accumulation}

In the case of restoration by afforestation, the success of reclamation mainly depends on the type of plant species selected for revegetation for the particular site and climate [28]. The most common vegetations types used for restoration are mixed forest, deciduous, ever green, legumes, and grass $[4,62,63]$. Different tree species play different roles in amending mine soil properties even in the same climate [38,64-66]. Field experiment studies indicated significant differences in the SOC stocks under different afforested trees on the same soil substrate, which may be due to the amount of litter, the decomposition of dead roots, and the elemental composition of the individual biomass [37,67]. The decomposition of leaf litter releases the bound nutrients into the soil, which increases the SOC concentration of mine soils over time [62]. Ahirwal and Maiti [59] stated that the increase in SOC concentration is due to the accumulation of leaf litter and its subsequent decomposition to humus. Yan et al. [44] recommended Quercus liaotungensis compared with Rhus typhina and Pinus tabuliformis is associated with its significantly higher organic carbon sequestration rate (1.59 $\left.\mathrm{t} \mathrm{ha}^{-1} \mathrm{yr}^{-1}\right)$ for reclamation management of degraded mining lands in China. Frouz et al. [48] also observed significantly different SOC accumulation rates among different tree species, ranging from 0.15 to $1.28 \mathrm{t} \mathrm{ha}^{-1} \mathrm{yr}^{-1}$ in post-mining sites in the Czech Republic. 
Table 1. The effect of age on soil organic carbon accumulation.

\begin{tabular}{|c|c|c|c|c|c|c|c|c|c|}
\hline Tree Species & $\begin{array}{l}\text { Age of the } \\
\text { Plantation }\end{array}$ & $\begin{array}{l}\text { SOC Total Stock } \\
\left(\mathrm{Mg} \mathrm{ha}^{-1}\right)\end{array}$ & $\begin{array}{c}\text { SOC Accumulation } \\
\text { Rate (Mg ha }{ }^{-1} \text { Year }^{-1} \text { ) }\end{array}$ & Soil Depth (cm) & MAP(mm) & MAT $\left({ }^{\circ} \mathrm{C}\right)$ & $\begin{array}{l}\text { Reclaimed Mine Soil } \\
\text { Substrate Type }\end{array}$ & $\begin{array}{l}\text { General Reclamation } \\
\text { Techniques }\end{array}$ & References \\
\hline \multirow[b]{2}{*}{ Mixed Forest } & 5 & 9.11 & 1.82 & \multirow[b]{2}{*}{$0-20$} & \multirow[b]{2}{*}{1000} & \multirow[b]{2}{*}{26} & \multirow[b]{2}{*}{ Coal } & \multirow{2}{*}{$\begin{array}{l}\text { Top soil with mixed } \\
\text { forest }\end{array}$} & \multirow[b]{2}{*}{ [28] } \\
\hline & 10 & 19.89 & 1.99 & & & & & & \\
\hline Quercus liaotungensis & \multirow{2}{*}{11} & 32.59 & 1.59 & \multirow[b]{2}{*}{$0-30$} & \multirow{2}{*}{431.1} & \multirow{2}{*}{10.0} & \multirow{2}{*}{ Coal } & \multirow{2}{*}{$\begin{array}{l}\text { Leveling and top } \\
\text { soiling }\end{array}$} & \multirow{2}{*}{ [44] } \\
\hline Pinus tabuliformis & & 16.04 & 0.37 & & & & & & \\
\hline \multirow{3}{*}{$\begin{array}{c}\text { Mixed Acacia } \\
\text { auriculiformis, } \\
\text { Sennasiamea, Acacia } \\
\text { catechu and Dalbergia } \\
\text { sissoo }\end{array}$} & 3 & 1.83 & 0.61 & \multirow{3}{*}{$0-15$} & \multirow{3}{*}{1375} & \multirow{3}{*}{25.7} & \multirow{3}{*}{ Coal } & \multirow{3}{*}{$\begin{array}{l}\text { Regrading of spoil } \\
\text { materials and } \\
\text { plantation of tree } \\
\text { species }\end{array}$} & \multirow{3}{*}{ [8] } \\
\hline & 10 & 5.82 & 0.58 & & & & & & \\
\hline & 15 & 7.60 & 0.51 & & & & & & \\
\hline \multirow{6}{*}{ Prosopis juliflora } & 2 & 8.1 & 4.05 & \multirow{6}{*}{$0-60$} & \multirow{6}{*}{975} & \multirow{6}{*}{27.5} & \multirow{6}{*}{ Coal } & \multirow{6}{*}{$\begin{array}{l}\text { Regrading and top } \\
\text { soiling }\end{array}$} & \multirow{6}{*}{ [33] } \\
\hline & 3 & 12.6 & 4.20 & & & & & & \\
\hline & 4 & 17 & 4.25 & & & & & & \\
\hline & 5 & 19.2 & 3.84 & & & & & & \\
\hline & 6 & 27.5 & 4.58 & & & & & & \\
\hline & 8 & 45.4 & 5.68 & & & & & & \\
\hline \multirow{2}{*}{ Robinia pseudoacacia L. } & 2 & 11.7 & \multirow[b]{2}{*}{4} & & & & & NK fertilization, and & \\
\hline & 14 & 59.8 & & $0-30$ & 569 & 9.4 & Lignite & $\begin{array}{l}\text { spread of a mixture of } \\
\text { rye and alfalfa }\end{array}$ & [45] \\
\hline & 2 & 1.1 & 0.55 & & & & & Top soiling, farm yard & \\
\hline Dalbergia sissoo & 16 & 8.91 & 0.56 & $0-15$ & 1308 & 27 & Coal & $\begin{array}{c}\text { manure, and NPK } \\
\text { fertilizers }\end{array}$ & [46] \\
\hline & 5 & 7.02 & 1.40 & & & & & Loose-graded, & \\
\hline Mixed Forest & 11 & 13.52 & 1.23 & $0-25$ & 1230 & 16.2 & Coal & hydroseeded, and & [47] \\
\hline & 21 & 21.35 & 1.02 & & & & & NPK & \\
\hline Alder (Alnus glutinosa) & 28 & 33.49 & 1.20 & & & & & & \\
\hline Lime (Tilia cordata) & 31 & 34.51 & 1.12 & & & & & & \\
\hline Oak (Quercus robur) & 28 & 15.01 & 0.54 & $0-20$ & 650 & 6.8 & Coal & $\mathrm{n} / \mathrm{a} *$ & {$[48,49]$} \\
\hline Spruce (Picea sp.) & 27 & 8.46 & 0.32 & & & & & & \\
\hline Pine (Pinus sp.) & 22 & 8.80 & 0.40 & & & & & & \\
\hline
\end{tabular}


Table 1. Cont.

\begin{tabular}{|c|c|c|c|c|c|c|c|c|c|}
\hline Tree Species & $\begin{array}{l}\text { Age of the } \\
\text { Plantation }\end{array}$ & $\begin{array}{l}\text { SOC Total Stock } \\
\left(\mathrm{Mg} \mathrm{ha}^{-1}\right)\end{array}$ & $\begin{array}{l}\text { SOC Accumulation } \\
\text { Rate }\left(\mathrm{Mg} \mathrm{ha}^{-1} \text { Year }^{-1}\right)\end{array}$ & Soil Depth (cm) & MAP(mm) & $\operatorname{MAT}\left({ }^{\circ} \mathrm{C}\right)$ & $\begin{array}{l}\text { Reclaimed Mine Soil } \\
\text { Substrate Type }\end{array}$ & $\begin{array}{l}\text { General Reclamation } \\
\text { Techniques }\end{array}$ & References \\
\hline \multirow{4}{*}{ Casuarina equisetifolia } & 6 & 3.19 & 0.53 & \multirow{4}{*}{$0-30$} & \multirow{4}{*}{1228} & \multirow{4}{*}{21.7} & \multirow{4}{*}{ Heavy mineral } & \multirow{4}{*}{$\begin{array}{l}\text { Topsoil with a seed } \\
\text { mixture of short-lived } \\
\text { annual species }\end{array}$} & \multirow{4}{*}{ [50] } \\
\hline & 9 & 3.75 & 0.42 & & & & & & \\
\hline & 12 & 9.35 & 0.78 & & & & & & \\
\hline & 15 & 11.55 & 0.77 & & & & & & \\
\hline \multirow{3}{*}{ Mixed Forest } & 2 & 5.4 & 2.70 & \multirow{3}{*}{$0-30$} & \multirow{3}{*}{975} & \multirow{3}{*}{23} & \multirow{3}{*}{ Coal } & \multirow{3}{*}{ Only backfilled dumps } & \multirow{3}{*}{ [51] } \\
\hline & 8 & 16.4 & 2.05 & & & & & & \\
\hline & 14 & 26.4 & 1.89 & & & & & & \\
\hline \multirow{2}{*}{$\begin{array}{l}\text { Scots pines and giant } \\
\text { miscanthus plants. }\end{array}$} & \multirow{2}{*}{$\mathrm{n} / \mathrm{a}$} & 33 & $\mathrm{n} / \mathrm{a}$ & \multirow{2}{*}{$0-20$} & \multirow{2}{*}{$\mathrm{n} / \mathrm{a}$} & \multirow{2}{*}{$\mathrm{n} / \mathrm{a}$} & \multirow{2}{*}{ Lignite } & Sewage sludge & \multirow{2}{*}{ [52] } \\
\hline & & 45 & $\mathrm{n} / \mathrm{a}$ & & & & & Compost & \\
\hline \multirow[t]{2}{*}{ Scots pines } & \multirow{2}{*}{25} & 27.2 & 1.1 & \multirow{2}{*}{ O to $\mathrm{C} 2$ horizon } & \multirow{2}{*}{$\mathrm{n} / \mathrm{a}$} & \multirow{2}{*}{$\mathrm{n} / \mathrm{a}$} & \multirow[t]{2}{*}{ Lignite } & $\begin{array}{l}\text { Liming and NPK } \\
\text { fertilizers }\end{array}$ & \multirow[t]{2}{*}{ [53] } \\
\hline & & 37.4 & 1.50 & & & & & NPK fertilizers & \\
\hline \multirow{6}{*}{ Scots pines } & 12 & 63.1 & 5.20 & \multirow[b]{2}{*}{$0-110$} & \multirow[b]{2}{*}{580} & \multirow[b]{2}{*}{7.6} & \multirow[b]{2}{*}{ Lignite } & Liming, NPK & \multirow{6}{*}{ [54] } \\
\hline & 17 & 45.9 & 2.70 & & & & & $\begin{array}{l}\text { fertillzation and } \\
\text { sowing a mixture of } \\
\text { grasses and } \\
\text { leguminous plants }\end{array}$ & \\
\hline & 21 & 22.6 & 1.08 & & & & & Top soiling, NPK & \\
\hline & 23 & 16.8 & 0.73 & $0-110$ & 700 & 8 & Sand & $\begin{array}{l}\text { fertilization, and } \\
\text { lupine as green } \\
\text { manure }\end{array}$ & \\
\hline & 30 & 65.0 & 2.17 & 0-110 & 650 & 7 & Sulfur & Leguminous and grass & \\
\hline & 30 & 34.4 & 1.15 & $0-110$ & & & sumul & $\begin{array}{l}\text { crop with NPK } \\
\text { fertilization }\end{array}$ & \\
\hline Pasture land & 25 & 36.7 & 1.47 & $0-30$ & $\mathrm{n} / \mathrm{a}$ & $n / a$ & Coal & Grading and & [55] \\
\hline Forest land & & 37.1 & 1.48 & & 11/ a & & tonar & top and subsoils & \\
\hline
\end{tabular}

${ }^{*} \mathrm{n} / \mathrm{a}=$ data is not available. 
Yao et al. [68] indicated that the physical and chemical properties of the soil of a 15-yearold reclaimed coal mine improved and concluded that different tree species have varying degrees of influence on soil forming process. This may also be due to the tree species effect on the soil fauna communities, which are vital for the decomposition of litterfall. For example, the soil environment created by pine litter is relatively more unfavorable for fast decomposition [69] due to its acidic reaction that hampers development of the soil fauna community [70]. However, Zeng et al. [71] revealed that the litter decomposition rate of broad-leaved trees was significantly higher than that of coniferous evergreen trees, which may result in the difference in carbon input into the soil. Similarly, Šourková et al. [72] suggested that vegetation type has a greater impact on the microbial community than the substrate and measured the highest values of microbial biomass under oak and alder compared with pine trees. Trees with good litter quality exhibit higher microbial biomass carbon. Moreover, the existence of microorganisms in soil can increase soil aggregation and can enhance soil fertility by improving the nutrients $[73,74]$. These increase the $C$ storage potential of the soil by creating conducive environments that facilitate the establishment of mosses, lichens, and herbaceous and perennial plants [75].

Vegetation affects soil respiration by influencing the soil microclimate and structure, the quantity of detritus supplied to the soil, the quality of that detritus, and the overall rate of root respiration [76]. Tewary et al. [77] found that the soil respiration rates beneath coniferous trees were lower than those beneath broad-leaved trees in a mixed forest in northern India. Pietrzykowski [78] also mentioned the value of the selective choice of tree species for afforestation of post-mining areas to accelerate the development of technogenic soil substrates. Therefore, the selection of the right tree species is a prime concern for SOC improvement in RMS due to the unfavorable mine spoil characteristics, such as high rock fragments (60-80\%), low water-holding capacity, low $\mathrm{pH}$, high bulk density, poor microbial activity, and low nutrient content [51,79].

The difference in vegetation cover also resulted in significant variations in the rates of carbon accumulation at the same age in different ways. For example, Sperow [56] estimated that pasture had higher soil $C$ sequestration rates than forest soil. Rehabilitation using grass enhanced the early accumulation of SOC in RMS compared with the others, which may be due to grass land accumulating larger portions of carbon in soil while forests allocate large portions in biomass. Chatterjee et al. [80] also observed a maximum accumulation of SOC in grass land at 9 years $\left(29.5 \mathrm{Mg} \mathrm{ha}^{-1}\right)$ after reclamation and an almost similar amount after 30 years $\left(29.7 \mathrm{Mg} \mathrm{ha}^{-1}\right)$. The findings of Shrestha and Lal [20] indicated that $81 \%$ of carbon is accumulated in tree biomass such as aboveground biomass, roots, and litter and that the remaining $19 \%$ of the carbon is accumulated in the soil in a forest ecosystem. Similarly, 77 to $82 \%$ of carbon accumulation in plant biomass in the forest ecosystem was also reported by Amichev et al. [81]. In the grass land ecosystem, however, $84 \%$ of carbon was accumulated in the soil [20]. Akala and Lal [37] observed that $48 \mathrm{Mg} \mathrm{ha}^{-1}$ of SOC was stored in forest after 21 years and that pasture stored $55 \mathrm{Mg} \mathrm{ha}^{-1}$ of SOC after 25 years.

However, not all studies confirm the higher $C$ sequestration under pastures compared with forests at post-mining sites. As indicated in Table 1, a study conducted in the USA in conditions of reclaimed post-mining soils showed that the SOC sequestered at a $0-30 \mathrm{~cm}$ depth in post-mining soils over 25 years was similar for pastures and forest [55]. A study conducted in reclaimed mine soils in Ohio (USA) showed that the conversion of pastures to Australian pine (Casuarina spp.) and Black locust (Robinia pseudoaccacia L.) increased the SOC pool in the top $50 \mathrm{~cm}$ of soil [39]. Some studies revealed a higher amount of SOC accumulation under legume vegetation types than grass elsewhere. For example, the study of Kumari and Maiti [62] revealed that the rates of SOC accumulation $\left(1.57 \mathrm{Mg} \mathrm{SOC} \mathrm{ha}{ }^{-1}\right.$ year $^{-1}$ ) under legume were higher than that for grass. Legumes showed advantages over the grass species in restoring mine soil fertility.

Climate determines the type of vegetation used for afforestation, and therefore for the accumulation of SOC in RMS. For a better accumulation of SOC, Vindušková and Frouz [49] suggested that grasses should be planted at warmer sites, that conifers should be planted at 
colder sites, and that deciduous trees should be planted at intermediate sites. Soil moisture is also an important factor in the accumulation of organic carbon in the soil. A higher SOC accumulation is observed where the moisture content is high. For example, the findings of $\mathrm{Li}$ et al. [63] indicated that moisture level had an effect on carbon accumulation. A higher moisture content results in high biomass production, thereby increasing the accumulation of organic carbon in forest soil.

Additionally, inputs of organic matter from plantations of different tree species positively influence the $\mathrm{C}, \mathrm{N}$, and $\mathrm{P}$ contents, $\mathrm{pH}$, water-holding capacity (WHC), and bulk density (BD) of the RMS [36,58]. Izquierdo et al. [82] revealed a decrease in BD after planting trees in the degraded mining sites. The soil loosens due to soil organic carbon following the growth and development of roots decreases soil bulk density [37]. Additionally, different research indicated significant increases in the C, N, and P contents and WHC due to the accumulation of litterfall and decomposition, forming humus $[20,83,84]$. All of these improvements enhance the growth of diversified plants, and soil development thus increases carbon storage in RMS.

\subsection{The Effect of Reclamation Treatments on SOC Accumulation}

The reclamation of degraded mine soil facilitates easy establishment of vegetations by improving the physical and chemical properties of the soil substrate, thereby improving the SOC. The most commonly applied mining site reclamation methods are backfilling, regrading, and applying topsoil [8,28,51]; forming and leveling of the surface, hydroseeding [47], and adding topsoil with a seed mixture of short-lived annual species [50]; and adding green manure, using mineral fertilization with NPK, and liming [21,60]. All of the listed reclamation methods significantly improved the severely degraded mining site substrate to support plant growth. Reclamation of the mine site with the addition of topsoil and spreading a mixture of grass seeds before afforestation of fast-growing trees accounted for $9.03 \mathrm{Mg} \mathrm{C} \mathrm{ha}{ }^{-1}$ stock in a 5-year-old reclaimed coal mine dump, which is five-fold higher than that of an unreclaimed mine [59]. Similarly, the results of Č́žková et al. [85] indicated the high potential of reclaimed grasslands with topsoil for $C$ sequestration, measured up to 1.6 $\mathrm{Mg} \mathrm{ha}{ }^{-1} \mathrm{y}^{-1}$. Thus, the application of topsoil creates more suitable conditions for soil organic matter accumulation.

The substrate varies significantly due to the variation in applied reclamation and therefore variation in SOC. Pietrzykowski et al. [21] recommended one year of lupine green manure cropping for the restoration of mine soil prior to vegetation due to its contribution of $13.55 \mathrm{Mg} \mathrm{ha}^{-1}$ of SOC compared with two-year lupine cultivation $\left(9.5 \mathrm{Mg} \mathrm{ha}^{-1}\right)$, oneyear fallow and two-year lupin cultivation (10.23 $\left.\mathrm{Mg} \mathrm{ha}^{-1}\right)$, and two-year fallow and lupin cultivation $\left(8.4 \mathrm{Mg} \mathrm{ha}^{-1}\right)$. However, the parent material also strongly determines the SOC accumulation even under the same reclamation methods applied. In another comparative study of soil development under succession and after reclamation in the same area, Pietrzykowski and Krzaklewski [60] found significantly higher SOC accumulation in reclaimed soils.

Antonelli et al. [86] also indicated that the amendment of biosolids in mine site reclamation after 13 years has the significant influence on SOC sequestration $\left(6.3 \mathrm{Mg} \mathrm{ha}^{-1} \mathrm{yr}^{-1}\right)$ compared with in an unamended mine site $\left(0.72 \mathrm{Mg} \mathrm{ha}^{-1} \mathrm{yr}^{-1}\right)$. Thus, the application of any of the reclamation methods enhances colonization of microorganisms and early establishment of vegetation that contributes to SOC accumulation in RMS. However, a gap still exists between studies comparing the effects of mine site soil reclamation methods on SOC accumulation.

\section{Conclusions}

The restoration of mine soil is a global issue that needs scientific investigation due to the vulnerability and complexity of mining sites. The factors associated with mining, such as top soil removal, compaction, contamination, and removal of organic matter result in drastic changes in the physicochemical properties of mine soil. Restored mining sites 
perform ecological functions important for increasing the resilience to climate change in the environment and provide important ecosystem services, among which $C$ sequestration is regarded as the most significant. Experimental studies have shown that the restoration of mining sites increase soil organic carbon sequestration. However, the amount of SOC accumulation in RMS is mainly affected by the development rate of restoration, the vegetation type, the climate, the soil moisture, and the substrate or type of reclamation applied. The implementation of reclamation greatly facilitates successful occupation of microorganisms and establishment of plants at the site. These findings also reveal that inoculating microorganisms such as bacteria, cyanobacteria, or a combination of them increases the sequestrated $C$ in the soil. The effect of restoration on SOC is predominantly found to be specific to species, reclamation methods, and age. Thus, choice and management of appropriate reclamation methods and tree species require a detailed understanding of the substrate type and climatic factors for successful accumulation of SOC in RMS. Even though reclamation enhances the successful establishment of planted trees, the number of cost-effect studies is lacking. Therefore, the cost effectiveness of different reclamation methods and its effect on SOC storage studies are recommended.

Author Contributions: A.M.M.; writing—original draft preparation, M.P. and B.W.; revision and editing. All authors have read and agreed to the published version of the manuscript.

Funding: This paper was supported by a project founded from the European Union's Horizon 2020 research and innovation programme under grant agreement No. 836819 (TRACER-H2020-LC-SC32018-2019-2020)

Conflicts of Interest: The authors declare no conflict of interest.

\section{References}

1. Bell, F.G.; Donnelly, L.J. Mining and Its Impact on the Environment; Taylor \& Francis: London, UK; New York, NY, USA, 2006.

2. Feng, Y.; Wang, J.; Bai, Z.; Reading, L. Effects of surface coal mining and land reclamation on soil properties: A review. Earth-Sci. Rev. 2019, 191, 12-25. [CrossRef]

3. Wick, A.F.; Stahl, P.D.; Ingram, L.J.; Vicklund, L. Soil aggregation and organic carbon in short-term stockpiles. Soil Use Manag. 2009, 25, 311-319. [CrossRef]

4. Mukhopadhyay, S.; Masto, R.E.; Yadav, A.; George, J.; Ram, L.C.; Shukla, S.P. Soil quality index for evaluation of reclaimed coal mine spoil. Sci. Total Environ. 2016, 542, 540-550. [CrossRef] [PubMed]

5. Shrestha, R.K.; Lal, R. Changes in physical and chemical properties of soil after surface mining and reclamation. Geoderma 2011, 3-4, 168-176. [CrossRef]

6. Maiti, S.K. Ecorestoration of the Coalmine Degraded Lands; Springer: New Delhi, India, 2013.

7. Ussiri, D.A.N.; Lal, R. Carbon sequestration in reclaimed mine soils. Crit. Rev. Plant Sci. 2005, 24, 151-165. [CrossRef]

8. Ahirwal, J.; Kumar, A.; Pietrzykowski, M.; Maiti, S.K. Reclamation of coal mine spoil and its effect on Technosol quality and carbon sequestration: A case study from India. Environ. Sci. Pollut. Res. 2018, 25, 27992-28003. [CrossRef]

9. Pietrzykowski, M. Soil quality index as a tool for Scots pine (Pinus sylvestris) monoculture conversion planning on afforested, reclaimed mine land. J. For. Res. 2014, 25, 63-74. [CrossRef]

10. Macdonald, S.E.; Landhäusser, S.M.; Skousen, J.; Franklin, J.; Frouz, J.; Hall, S.; Jacobs, D.F.; Quideau, S. Forest restoration following surface mining disturbance: Challenges and solutions. New For. 2015, 46, 703-732. [CrossRef]

11. Bradshaw, A. The use of natural processes in reclamation- advantages and difficulties. Landsc. Urban Plan. 2000, 51, 89-100. [CrossRef]

12. Pietrzykowski, M. Soil and plant communities development and ecological effectiveness of reclamation on a sand mine cast. J. For. Sci. 2008, 54, 554-565. [CrossRef]

13. Pietrzykowski, M.; Socha, J. An estimation of Scots pine (Pinus sylvestris L.) ecosystem productivity on reclaimed post-mining sites in Poland (central Europe) using of allometric equations. Ecol. Eng. 2011, 37, 381-386. [CrossRef]

14. Asensio, V.; Vega, F.A.; Andrade, M.L.; Covelo, E.F. Tree vegetation and waste amendments to improve the physical condition of copper mine soils. Chemosphere 2013, 90, 603-610. [CrossRef]

15. Srivastava, N.K.; Ram, L.C.; Masto, R.E. Reclamation of overburden and lowland in coal mining area with fly ash and selective plantation: A sustainable ecological approach. Ecol. Eng. 2014, 71, 479-489. [CrossRef]

16. Pietrzykowski, M.; Krzaklewski, W. Reclamation of Mine Lands in Poland. In Bio-Geotechnologies for Mine Site Rehabilitation; Elsevier: Amsterdam, The Netherlands, 2018; pp. 493-513. 
17. Pietrzykowski, M.; Woś, B.; Haus, N. Scots pine needles macronutrient (N, P, K, CA, MG, and S) supply at different reclaimed mine soil substrates as an indicator of the stability of developed forest ecosystems Environ. Monit. Assess. 2013, 185, 7445-7457. [CrossRef]

18. Wanga, D.; Zhanga, B.; Zhua, L.; Yang, Y.; Li, M. Soil and vegetation development along a 10-year restoration chronosequence in tailing dams in the Xiaoqinling gold region of Central China. Catena 2018, 167, 250-256. [CrossRef]

19. Maharana, K.J.; Patel, K.A. Microbial biomass, microbial respiration and organic carbon indicates nutrient cycling in a chronosequence coal mine overburden spoil. IJES 2013, 4, 171-184.

20. Shrestha, R.K.; Lal, R. Carbon and nitrogen pools in reclaimed land under forest and pasture ecosystems in Ohio, USA. Geoderma 2010, 157, 196-205. [CrossRef]

21. Pietrzykowski, M.; Gruba, P.; Sproull, G. The effectiveness of Yellow lupine (Lupinus luteus L.) green manure cropping in sand mine cast reclamation. Ecol. Eng. 2017, 102, 72-79. [CrossRef]

22. Otremba, K.; Kozłowski, M.; Tatusko-Krygier, N.; Pająk, M.; Kołodziej, B.; Bryk, M. Impact of alfalfa and NPK fertilization in agricultural reclamation on the transformation of Technosols in an area following lignite mining. Land Degrad. Dev. 2020, 32, 1179-1191. [CrossRef]

23. Reverchon, F.; Yang, H.; Ho, T.Y.; Yan, G.; Wang, J.; Xu, Z.; Zhang, D. A preliminary assessment of the potential of using an acacia-biochar system for spent mine site rehabilitation. Environ. Sci. Pollut. Res. 2014, 22, 2138-2144. [CrossRef]

24. Moghimian, N.; Hosseini, S.M.; Kooch, Y.; Darki, B.Z. Impacts of changes in land use/cover on soil microbial and enzyme activities. Catena 2017, 157, 407-414. [CrossRef]

25. León, J.D.; Castellanos, J.; Casamitjana, M.; Osorio, N.W.; Loaiza, J.C. Alluvial gold-mining degraded soils reclamation using Acacia mangium Wild. plantations: An evaluation from biogeochemistry. In Plantations Biodiversity, Carbon Sequestration and Restoration; Hai, R., Ed.; Nova Sci Publishers: New York, NY, USA, 2013; pp. 155-176.

26. Josa, R.; Jorba, M.; Vallejo, V.R. Opencast mine restoration in a Mediterranean semiarid environment: Failure of some common practices. Ecol. Eng. 2012, 42, 183-191. [CrossRef]

27. Zhao, Z.; Bai, Z.; Zhang, Z.; Guo, D.; Li, J.; Xu, Z.; Pan, Z. Population structure and spatial distributions patterns of 17 years old plantation in a reclaimed spoil of Pingshuo opencast mine, China. Ecol. Eng. 2012, 44, 147-151. [CrossRef]

28. Bandyopadhyay, S.; Novo, L.A.B.; Pietrzykowski, M.; Maiti, S.K. Assessment of Forest Ecosystem Development in Coal Mine Degraded Land by Using Integrated Mine Soil Quality Index (IMSQI): The Evidence from India. Forests 2020, 11, 1310. [CrossRef]

29. Restrepo, M.F.; Flórez, C.P.; Osorio, N.W.; León, J.D. Passive and active restoration strategies to activate soil biogeochemical nutrient cycles in a degraded tropical dry land. Int. Sch. Res. Not. 2013, 1-6. [CrossRef]

30. Chaudhuri, S.; McDonald, L.M.; Skousen, J.; Pena-Yewtukhiw, E.M. Soil organic carbon molecular properties: Effects of time since reclamation in a mine soil chronosequence. Land Degrad. Dev. 2013, 26, 237-248. [CrossRef]

31. Wick, A.F.; Daniels, W.L.; Orndorff, Z.W.; Alley, M.M. Organic matter accumulation post-mineral sands mining. Soil Use Manag. 2013, 29, 354-364. [CrossRef]

32. Bodlák, L.; Krováková, K.; Kobesová, M.; Brom, J.; Stastny, J.; Pecharová, E. SOC content-An appropriate tool for evaluating the soil quality in a reclaimed post-mining landscape. Ecol. Eng. 2012, 43, 53-59. [CrossRef]

33. Ahirwal, J.; Maiti, S.K.; Reddy, M.S. Development of carbon, nitrogen and phosphate stocks of reclaimed coal mine soil within 8 years after forestation with Prosopis juliflora (Sw.) Dc. Catena 2017, 156, 42-50. [CrossRef]

34. Barlizaa, C.J.; Rodrígueza, B.O.; León Peláeza, D.J.; Chávez, F.L. Planted forests for open coal mine spoils rehabilitation in Colombian drylands: Contributions of fine litterfall through an age chronosequence. Ecol. Eng. 2019, 138, 180-187. [CrossRef]

35. Ivanova, E.; Pershina, E.; Karpova, D.; Rogova, O.; Abakumov, E.; Andronov, E. Soil microbiome in chronosequence of spoil heaps of Kursk Magnetic Anomaly. Biol. Commun. 2019, 64, 219-225. [CrossRef]

36. Mukhopadhyaya, S.; Maiti, S.K.; Masto, R.E. Development of mine soil quality index (MSQI) for evaluation of reclamation success: A chronosequence study. Ecol. Eng. 2014, 71, 10-20. [CrossRef]

37. Akala, V.A.; Lal, R. Soil organic carbon pools and sequestration rates in reclaimed minesoils in Ohio. J. Environ. Qual. 2001, 30, 2098-2104. [CrossRef] [PubMed]

38. Juwarkar, A.A.; Mehrotra, K.L.; Nair, R.; Wanjari, T.; Singh, S.K.; Chakrabarti, T. Carbon sequestration in reclaimed manganese mine land at Gumgaon, India. Environ. Monit. Assess. 2010, 160, 457-464. [CrossRef] [PubMed]

39. Ussiri, D.A.N.; Lal, R.; Jacinthe, P.A. Soil Properties and Carbon Sequestration of Afforested Pastures in Reclaimed Minesoils of Ohio. J. Soil Sci. Soc. Am. 2006, 70, 1797-1806. [CrossRef]

40. Zhang, P.P.; Zhang, Y.L.; Jia, J.C.; Cui, Y.X.; Wang, X.; Zhang, X.C.; Wang, Y.Q. Revegetation pattern affecting accumulation of organic carbon and total nitrogen in reclaimed mine soils. Peer J. 2020, 8, e8563. [CrossRef]

41. Shrestha, R.K.; Lal, R.; Jacinthe, P.A. Enhancing Carbon and Nitrogen Sequestration in Reclaimed Soils through Organic Amendments and Chiseling. J. Soil Sci. Soc. Am. 2009, 73, 1004-1011. [CrossRef]

42. Parajuli, P.B.; Duffy, S. Evaluation of Soil Organic Carbon and Soil Moisture Content from Agricultural Fileds in Mississipi. J. Soil Sci. 2013, 3, 81-90.

43. Hobley, E.U.; Wilson, B. The depth distribution of organic carbon in the soils of eastern Australia. Ecosphere 2016, 7, 1-21. [CrossRef]

44. Yan, M.; Fan, L.; Wang, L. Restoration of soil carbon with different tree species in a post-mining land in eastern Loess Plateau, China. Ecol. Eng. 2020, 158, 106025. [CrossRef] 
45. Matos, E.S.; Freese, D.; Böhm, C.; Quinkenstein, A.; Hüttl, R.F. Organic matter dynamics in reclaimed lignite mine soils under Robinia pseudoacacia L. plantations of different ages in Germany. Commun. Soil Sci. Plant Anal. 2012, 43, 745-755. [CrossRef]

46. Mukhopadhyay, S.; Masto, R.E. Carbon storage in coal mine spoil by Dalbergia sissoo Roxb. Geoderma 2016, $284,204-213$. [CrossRef]

47. Avera, B.N.; Strahm, B.D.; Burger, J.A.; Zipper, C.E. Development of ecosystem structure and function on reforested surface-mined lands in the Central Appalachian Coal Basin of the United States. New For. 2015, 46, 683-702. [CrossRef]

48. Frouz, J.; Pižl, V.; Cienciala, E.; Kalčík, J. Carbon storage in post-mining forest soil, the role of tree biomass and soil bioturbation. Biogeochemistry 2009, 94, 111-121. [CrossRef]

49. Vindušková, O.; Frouz, J. Soil carbon accumulation after open-cast coal and oil shale mining in Northern Hemisphere: A quantitative review. Environ. Earth Sci. 2013, 69, 1685-1698. [CrossRef]

50. Van Rooyen, M.W.; Van Rooyen, N.; Stoffberg, G.H. Carbon sequestration potential of post-mining reforestation activities on the KwaZulu-Natal coast, South Africa. Forestry 2013, 86, 211-223. [CrossRef]

51. Ahirwal, J.; Maiti, S.K. Assessment of carbon sequestration potential of revegetated coal mine overburden dumps: A chronosequence study from dry tropical climate. J. Environ. Manag. 2017, 201, 369-377. [CrossRef]

52. Placek-Lapaja, A.; Grobelaka, A.; Fijalkowskia, K.; Singhb, B.R.; Almåsb, A.R.; Kacprzak, M. Post-Mining soil as carbon storehouse under polish conditions. J. Environ. Manag. 2019, 238, 307-314. [CrossRef]

53. Greinert, A.; Drab, M.; Śliwińska, A. Storage Capacity of Organic Carbon in the Reclaimed Post-Mining Technosols. Environ. Prot. Eng. 2018, 44, 117-127. [CrossRef]

54. Pietrzykowski, M.; Daniels, W.L. Estimation of carbon sequestration by pine (Pinus sylvestris L.) ecosystems developed on reforested post-mining sites in Poland on differing mine soil substrates. Ecol. Eng. 2014, 73, 209-218. [CrossRef]

55. Akala, V.A.; Lal, R. Potential of mine land reclamation for soil organic carbon sequestration in Ohio. Land Degrad. Dev. 2000, 11, 289-297. [CrossRef]

56. Sperow, M. Carbon Sequestration Potential in Reclaimed Mine Sites in Seven East-Central States. J. Environ. Qual. 2006, 35, 1428. [CrossRef] [PubMed]

57. Filcheva, E.; Noustorova, M.; Gentcheva-Kostadinova, S.; Haigh, M.J. Organic accumulation and microbial action in surface coal-mine spoils. Pernik, Bulgaria. Ecol. Eng. 2000, 15, 1-15. [CrossRef]

58. Adeli, A.; Brooks, J.P.; Read, J.J.; McGrew, R.; Jenkins, J.N. Post-reclamation age effects on soil physical properties and microbial activity under forest and pasture ecosystems. Commun. Soil Sci. Plant Anal. 2018, 50, 20-34. [CrossRef]

59. Ahirwal, J.; Maiti, S.K. Development of Technosol properties and recovery of carbon stock after 16 years of revegetation on coal mine degraded lands, India. Catena 2018, 166, 114-123. [CrossRef]

60. Pietrzykowski, M.; Krzaklewski, W. Potential for carbon sequestration in reclaimed mine soil on reforested surface mining areas in Poland. Nat. Sci. 2010, 2, 1015-1021. [CrossRef]

61. Stahl, P.D.; Anderson, J.D.; Ingram, L.J.; Schuman, G.E.; Mummey, D.L. Accumulation of Organic Carbon in Reclaimed Coal Mine Soils of Wyoming. In Proceedings of the National Meeting of the American Society of Mining and Reclamation and the 9th Billings Land Reclamation Symposium, Billings, MT, USA, 3-6 June 2003.

62. Kumari, S.; Maiti, S.K. Reclamation of coalmine spoils with topsoil, grass, and legume: A case study from India. Environ. Earth Sci. 2019, 78, 429. [CrossRef]

63. Li, C.; Gao, S.; Zhang, J.; Zhao, L.; Wang, L. Moisture effect on soil humus characteristics in a laboratory incuba-tion experiment. Soil Water Res. 2016, 11, 37-43. [CrossRef]

64. Mukhopadhyay, S.; Maiti, S.K.; Masto, R.E. Use of Reclaimed Mine Soil Index (RMSI) for screening of tree species for reclamation of coal mine degraded land. Ecol. Eng. 2013, 57, 133-142. [CrossRef]

65. Mukhopadhyay, S.; Maiti, S.K. Trace metal accumulation and natural mycorrhizal colonisation in an afforested coalmine overburden dump-a case study from India. Int. J. Min. Reclam. Environ. 2011, 25, 187-207. [CrossRef]

66. Mendes Filho, P.F.; Vasconcellos, R.L.F.; de Paula, A.M.; Cardoso, E.J.B.N. Evaluating the potential of forest species under microbial management for the restoration of degraded mining areas. Water Air Soil Poll. 2010, 208, 79-89. [CrossRef]

67. Ahirwal, J.; Kumar, A.; Maiti, S.K. Effect of Fast-Growing Trees on Soil Properties and Carbon Storage in an Afforested Coal Mine Land (India). Minerals 2020, 10, 840. [CrossRef]

68. Yao, F.U.; Changcun, L.I.N.; Jianjun, M.A.; Tingcheng, Z.H.U. Effects of plant types on physico-chemical properties of reclaimed mining soil in Inner Mongolia, China. Chin. Geogra. Sci. 2010, 20, 309-317.

69. Horodecki, P.; Jagodziński, A.M. Site Type Effect on Litter Decomposition Rates: A Three-Year Comparison of Decomposition Process between Spoil Heap and Forest Sites. Forests 2019, 10, 353. [CrossRef]

70. Smolander, A.; Kitunen, V. Soil microbial activities and characteristics of dissolved organic C and N in relation to tree species. Soil Biol. Biochem. 2002, 34, 651-660. [CrossRef]

71. Zeng, Q.C.; Li, X.; Dong, Y.H.; Li, Y.Y.; An, S.S. Soil microbial biomass nitrogen and carbon, water soluble nitrogen and carbon under different arbors forests on the Loess Plateau. Acta Ecol. Sinica 2015, 35, 3598-3605.

72. Šourková, M.; Frouz, J.; Fettweis, U.; Bens, O.; Hüttl, R.F.; Šantrucková, H. Soil development and properties of microbial biomass succession in reclaimed post-mining sites near Sokolov (Czech Republic) and near Cottbus (Germany). Geoderma 2005, 129, 73-80. [CrossRef] 
73. Bashan, Y.; de-Bashan, L.E. Microbial populations of arid lands and their potential for restoration of deserts. In Soil Biology and Agriculture in the Tropics; Springer: Berlin/Heidelberg, Germany, 2010; pp. 109-137.

74. Kheirfam, H.; Sadeghi, S.H.R.; Homaee, M.; Zarei Darki, B. Quality improvement of an erosion-prone soil through microbial enrichment. Soil Tillage Res. 2017, 165, 230-238. [CrossRef]

75. Molina-Montenegro, M.A.; Oses, R.; Atala, C.; Torres-Díaz, C.; Bolados, G.; León-Lobos, P. Nurse effect and soil microorganisms are key to improve the establishment of native plants in a semiarid community. J. Arid Environ. 2016, 126, 54-61. [CrossRef]

76. Raich, J.W.; Tufekcioglu, A. Vegetation and Soil respirations: Correlations and control. Biogeochemistry 2000, 48, 71-90. [CrossRef]

77. Tewary, C.K.; Pandey, U.; Singh, J.S. Soil and litter respiration rates in different microhabitats of a mixed oak-conifer forest and their control by edaphic conditions and substrate quality. Plant Soil. 1982, 65, 233-238. [CrossRef]

78. Pietrzykowski, M. Tree species selection and reaction to mine soil reconstructed at reforested post-mine sites: Central and eastern European experiences. Ecol. Eng. 2019, x3, 100012. [CrossRef]

79. Józefowska, A.; Pietrzykowski, M.; Woś, B.; Cajthaml, T.; Frouz, J. The effects of tree species and substrate on carbon sequestration and chemical and biological properties in reforested post-mining soils. Geoderma 2017, 292, 9-16. [CrossRef]

80. Chatterjee, A.; Lal, R.; Shrestha, R.K.; Ussiri, D.A.N. Soil carbon pools of reclaimed mine soils under grass and forest land uses. Land Degrad. Dev. 2009, 20, 300-307. [CrossRef]

81. Amichev, B.; Burger, J.A.; Rodrigue, J.A. Carbon sequestration by forests and soils on mind land in the Midwestern and Appalachian coalfields of the U.S. For. Ecol. Manag. 2008, 256, 1949-1959. [CrossRef]

82. Izquierdo, I.; Caravaca, F.; Alguacil, M.M.; Hernández, G.; Roldán, A. Use of microbiological indicators for evaluating success in soil restoration after revegetation of a mining area under subtropical conditions. Appl. Soil Ecol. 2005, 30, 3-10. [CrossRef]

83. Maharaj, S.; Barton, C.D.; Karathanasis, T.A.D.; Rowe, H.D.; Rimmer, S.M. Distinguishing "new" from "old" organic carbon in reclaimed coal mine sites using thermogravimetry: II. Field Valid. Soil Sci. 2007, 172, 302-312. [CrossRef]

84. Schwenke, G.D.; Ayre, L.; Mulligan, D.R.; Bell, L.C. Soil stripping and replacementfor the rehabilitation of bauxite-mined land atWeipa II. Soil organicmatter dynamics in mine soil chronosequences. Aust. J. Soil Res. 2000, 38, 371-393.

85. Č́ížková, B.; Woś, B.; Pietrzykowski, M.; Frouz, J. Development of soil chemical and microbial properties in reclaimed and unreclaimed grasslands in heaps after opencast lignite mining. Ecol. Eng. 2018, 123, 103-111. [CrossRef]

86. Antonelli, P.M.; Fraser, L.H.; Gardner, W.C.; Broersma, K.; Karakatsoulis, J.; Phillips, M.E. Long term carbon sequestration potential of biosolids-amended copper and molybdenum mine tailings following mine site reclamation. Ecol. Eng. 2018, 117, 38-49. [CrossRef] 